\title{
Terapia génica con citocinas contra cáncer cervicouterino
}

\author{
Víctor Hugo Bermúdez-Morales, M en C, ${ }^{(1,2)}$ \\ Oscar Peralta-Zaragoza, M en C, ${ }^{(1,2)}$ Vicente Madrid-Marina, Dr en C. ${ }^{(1)}$
}

Bermúdez-Morales VH, Peralta-Zaragoza O, Madrid-Marina V.
Terapia génica con citocinas contra
cáncer cervicouterino.
Salud Publica Mex 2005;47:458-468.

\section{Resumen}

La terapia génica es una excelente alternativa para el tratamiento de muchas enfermedades. La capacidad para manipular el DNA ha permitido dirigir la terapia génica para corregir la función de un gen alterado, aumentar la expresión de un gen o activar la respuesta inmune.Así, se puede proponer el uso del DNA como un medicamento capaz de controlar, corregir o curar una enfermedad. La terapia génica contra cáncer tiene un potencial enorme, $y$ en la última década se han obtenido resultados muy alentadores del uso del DNA para controlar diversas neoplasias en modelos animales, lo cual ha permitido su aplicación en protocolos experimentales en humanos. Esta revisión concentra una reseña de los fundamentos de la terapia génica y su aplicación en cáncer cervical, desde el punto de vista de las alteraciones de la respuesta inmune enfocadas al microambiente tumoral y el uso de las citocinas como moduladores de la respuesta inmune.

Palabras clave: cáncer cervical, citocinas, DNA, terapia génica, virus del papiloma humano

\author{
Bermúdez-Morales VH, Peralta-Zaragoza O, Madrid-Marina V. \\ Gene therapy with cytokines \\ against cervical cancer.
}

Salud Publica Mex 2005;47:458-468.

\section{Abstract}

Gene therapy is an excellent alternative for treatment of many diseases. Capacity to manipulate the DNA has allowed direct the gene therapy to correct the function of an altered gene, to increase the expression of a gene and to favour the activation of the immune response. This way, it can intend the use of the DNA like medication able to control, to correct or to cure many diseases. Gene therapy against cancer has an enormous potential, and actually the use of the DNA has increased to control diverse cancer in animal models, with very encouraging results that have allowed its applications in experimental protocols in human. This work concentrates a review of the foundations of the gene therapy and its application on cervical cancer, from the point of view of the alterations of the immune system focused on the tumour micro-environment, and the use of the cytokines as immunomodulators.

Key words: cervical cancer; cytokines; DNA; gene therapy; human papillomavirus
L a terapia génica consiste en el tratamiento, prevención o eliminación de alguna enfermedad mediante la transferencia de DNA o el uso de genes para reemplazar algún gen que esté alterado, que codifiquen para un antígeno de origen infeccioso, tumoral, o para moléculas inmunoreguladoras de la respuesta inmune como: citocinas y quimiocinas. En virtud de que esta tecnología intenta corregir el origen genético de una enfermedad y no sólo sus síntomas, tendrá un potencial enorme en la biomedicina moderna, por lo que se espera que sea impulsora de una nueva revolución en la terapia contra diversas enfermedades.

Los primeros protocolos de terapia génica fueron realizados con la idea inicial de corregir enfermedades

(I) Centro de Investigaciones sobre Enfermedades Infecciosas. Instituto Nacional de Salud Pública, Cuernavaca, Morelos, México.

(2) Facultad de Medicina, Universidad Nacional Autónoma de México. México, D. F. , México.

Fecha de recibido: 31 de mayo de 2005 - Fecha de aprobado: 28 de octubre de 2005 Solicitud de sobretiros:Vicente Madrid Marina. Director de Biología Molecular de Patógenos, Instituto Nacional de Salud Pública, Avenida Universidad 655, colonia Santa María Ahuacatitlán, 62502, Cuernavaca, Morelos, México. Correo electrónico: vmarina@correo.insp.mx 
con un origen genético hereditario bien definido, mediante la inserción de un gen funcional y reemplazar al gen defectuoso. Sin embargo, el uso de esta tecnología se ha extendido a diversas enfermedades con diferente origen, ya sea infeccioso, alérgico, enfermedades autoinmunes, enfermedades cardiovasculares y muy ampliamente en el tratamiento del cáncer.

Existen dos tipos básicos de terapia génica que han sido aplicados en humanos: la germinal y la somática. La terapia génica germinal introduce la modificación genética en las células reproductoras, en células precursoras de la línea germinal o en las células embrionarias en las primeras etapas del desarrollo. En el caso de las células germinales los efectos terapéuticos se manifiestan en los descendientes que se originan a partir de las células germinales tratadas. La terapia génica somática dirige la modificación genética a cualquier tejido corporal (o soma) inverso al fenotipo de la enfermedad. ${ }^{1}$ En este sentido, se pueden proponer varias formas de cómo abordar la corrección de los genes alterados. Una estrategia es mediante la inserción del gen normal dentro de una célula o tejido de interés, y reemplazar el gen alterado para reestablecer el fenotipo normal. Otra forma es generar un intercambio del gen anormal, mediante un proceso de recombinación homóloga, o bien, por medio de una regulación de un gen alterado; es decir, regular la expresión de los genes.

\section{Terapia génica contra el cáncer}

A pesar de los grandes avances obtenidos en la patología molecular y en el entendimiento del desarrollo y progresión tumoral, aún no se ha generado una vacuna como tratamiento para el cáncer. En contraste con las enfermedades hereditarias, caracterizadas por defectos monogénicos bien definidos, la mayoría de los tipos de cáncer en humanos se desarrollan a partir de múltiples pasos que involucran alteraciones en varios genes que son responsables del fenotipo neoplásico de las células malignas. ${ }^{2}$ De esta manera, mientras que la terapia génica por sustitución de un solo gen puede emplearse para corregir un defecto genético recesivo o dominante, no es una alternativa muy adecuada para el tratamiento contra el cáncer. Por esa razón, la mayoría de los tratamientos oncológicos enfocan su acción a inhibidores del ciclo celular, a macromoléculas que tienen una función alterada y a inmunoreguladores de la respuesta inmune, y utilizan drogas, enzimas, hormonas, factores de crecimiento, citocinas y receptores modificados, los cuales inciden en el mantenimiento de la actividad tumoral.

La terapia génica contra el cáncer propone reemplazar o alterar la expresión de algunos genes que promueven el proceso tumoral. Por ejemplo, la pérdida de genes supresores de tumor (como el gen p53) y la sobreexpresión de oncogenes (por ejemplo, K-ras) se han identificado en varias neoplasias. Esto ha permitido corregir una anormalidad genética por la inserción de una copia del gen normal y la reversión del fenotipo maligno asociado con la muerte de la célula tumoral., ${ }^{3,4}$ Sin embargo, aunque estos resultados son alentadores, esta alternativa no ha tenido aún el éxito esperado en su aplicación en modelos in vivo. Así, con la finalidad de incrementar la eficiencia terapéutica de este tipo de procedimientos, será necesario implementar nuevas estrategias para poder transferir genes a las células malignas, y evitar que las células normales sean afectadas.

Se han considerado una lista de genes que podrán ser usados en el tratamiento contra el cáncer mediante terapia génica. Estos incluyen: genes que codifican para citocinas y moléculas coestimuladoras de superficie celular; quimiocinas, las cuales son necesarias para activar la respuesta inmune sistémica contra antígenos específicos de tumor; genes que codifican para antígenos específicos de tumor. Por otro lado, se han publicado varios trabajos donde se usan genes que codifican para prodrogas o también llamados genes suicidas, como la timidina cinasa del virus Herpex simples, la nitroreductasa, la citocina desaminasa de Escherichia coli, la hidrogenasa de Clostridium acetobutylicum, la timidina fosfatasa, diferentes isoformas de citocromo P450, deoxicitidina cinasa y la flavodoxina. ${ }^{5}$ Adicionalmente, diversas estrategias y vehículos se han propuesto para transportar los genes terapéuticos hasta su sitio blanco (cuadro I).

\section{Respuesta inmune antitumoral}

La inmunovigilancia tumoral se mide mediante dos tipos de mecanismos: la respuesta inmune innata y la respuesta inmune adaptativa. La respuesta inmune innata se considera como la primera barrera contra las células tumorales, las cuales son reconocidas por un proceso independiente de antígeno. Este mecanismo es mediado por un patrón de receptores y de moléculas de superficie celular expresados en la célula tumoral. Entre las principales células que reconocen a la célula tumoral se encuentran las células asesinas naturales (células $\mathrm{NK}$ ), las cuales reconocen la baja o nula expresión de moléculas MHC I sobre la célula tumoral, así como proteínas relacionadas con estrés, como la expresión de MICA y MICB, que son ligandos de los receptores NKG2D expresados por las células NK. ${ }^{6}$

En relación con la respuesta inmune adaptativa, ésta requiere del reconocimiento de antígenos tumorales para reconocer y eliminar la célula tumoral por medio de las células efectoras de la respuesta inmune. Se ha demostrado que la respuesta inmune mediada por células es la 


\section{Cuadro I \\ Estrategias de VACUNAS MEDIANTE EL USO DE TERAPIA GÉNICA}

I) Vacunas basadas en plásmidos de DNA - DNA desnudo

- Gene gun

- Liposomas y lípidos catiónicos

Adyuvantes

Motivos CpGs

BCG

Fosfato de aluminio (AIPO4)

Fosfato de calcio

Sucrosa

Polibreno, etc.

2) Vacunas basadas en vectores vivos

- Vectores virales

Retrovirus

Virus de vaccinia

Adenovirus y virus adenoasociados

Alfavirus

Virus de estomatitis vesicular

Pseudovirus de VPH

- Vectores bacterianos

Listeria monocytogenes

Salmonella typhimurium

Mycobacterium bovis

3) Vacunas basadas en células

- Vacunas basadas en células dendríticas (DC)

Transcriben genes terapéuticos

Pulsadas con antígenos tumorales

- Vacunas basadas en células tumorales (CT)

$\mathrm{CT}$ que expresan antígenos tumorales

CT que expresan moléculas inmunoactivadoras

(citocinas y moléculas coestimuladoras)

más importante para eliminar las células neoplásicas. Esta respuesta es dependiente de la activación de los linfocitos $\mathrm{T}$ y de las células presentadoras de antígenos profesionales (APC). ${ }^{7}$ La activación de los linfocitos T, requiere que las células dendríticas (CD) capturen y procesen el detritus celular tumoral, migren a los nódulos linfáticos regionales para presentar los antígenos tumorales a los linfocitos $\mathrm{TCD}^{+}$mediante las moléculas del MHC clase I. En este proceso se activan tanto los linfocitos T CD4 ${ }^{+} \mathrm{y}$ $\mathrm{CD}^{+}$específicos contra péptidos tumorales, los cuales son reconocidos a través de las moléculas del MHC. Los linfocitos T CD8 ${ }^{+}$citotóxicos son los responsable de lisar y eliminar a las células tumorales, por el reconocimiento de péptidos tumorales asociados a las moléculas del MHC clase I expresado en la superficie de la célula tumoral. Por otro lado, los linfocitos $\mathrm{T} \mathrm{CD}^{+}$son los encargados de orquestar la respuesta inmune antitumoral, ya que están involucrados en la inducción y activación de los linfocitos T CD8 ${ }^{+}$citotóxicos a través de la producción de citocinas. Además, los linfocitos T $\mathrm{CD}^{+}$son capaces de interactuar con las células APCs en el proceso de presentación de antígenos tumorales (priming) y activar a los precursores de linfocitos T CD8 ${ }^{+}$(figura 1). ${ }^{8,9}$

\section{Citocinas y microambiente tumoral}

Muchos de los eventos de la respuesta inmune están regulados por moléculas solubles llamadas citocinas, las cuales son secretadas por una gran variedad de tipos celulares, pero principalmente las producen los linfocitos $\mathrm{TCD}^{+}$. Las citocinas son proteínas de bajo peso molecular, que pueden secretarse o permanecer unidas a la membrana celular. Para realizar su función biológica se requieren en concentraciones de nanogramos a picogramos. Las citocinas actúan de manera autócrina al modular la actividad celular, o de manera parácrina al inducir la producción de otras citocinas mediante otras estirpes celulares. Además, las citocinas son importantes en la regulación de la proliferación y diferenciación celular, en la quimiotáxis celular y en la activación de células de la respuesta inmune. ${ }^{10}$ Las citocinas se secretan en respuesta a una amplia variedad de estímulos como: estrés celular, lesiones inducidas por carcinógenos, infecciones o inflamación. En este contexto, las citocinas estimulan la respuesta del huésped al controlar el estrés y la homeostasis celular.

En general, hay dos grupos de citocinas que pueden ser distinguibles con base en su participación en los procesos de infección y/o inflamación. Las citocinas que están directa o indirectamente involucradas en los procesos inflamatorios reciben el nombre de citocinas proinflamatorias [la interleucina (IL)-1, IL-2, IL-6, el interferón (IFN)$\gamma$ y el factor de necrosis tumoral (TNF)- $\alpha$ ] y promueven la respuesta inmune mediada por células. Las citocinas que suprimen la actividad de las citocinas proinflamatorias son las citocinas antiinflamatorias. Por ejemplo, IL-4, IL-10 e IL-13, que son potentes mediadores de los linfocitos B. De esta manera, el perfil de expresión de citocinas presentes en una enfermedad determinará el tipo de respuesta inmune que se genere. ${ }^{11,12}$

Recientemente, se ha determinado que en diversos tipos de cáncer se genera un microambiente tumoral, a causa de la expresión o represión de diferentes genes (como Fas, ligando de Fas, citocinas y quimiocinas), importantes en la respuesta inmune y de la célula tumoral; también se producen citocinas inmunosupresoras en el sitio tumoral, las cuales favorecen la progresión del proceso neoplásico. ${ }^{13}$ En virtud de que las citocinas tienen funciones pleiotrópicas, es difícil determinar la participación de una citocina en particular en la progresión del cáncer. Esto se debe a la relación con otras citocinas, factores de crecimiento y hormonas, que actúan simultáneamente en el sitio del tumor, así como con el blanco celular sobre el que actúan. ${ }^{14}$ Hay dos mecanismos que pueden explicar la participación de las citocinas en el desarrollo del cáncer. 1) Es posible que las citocinas favorezcan el desarrollo tumoral al interactuar con factores de proliferación, inducir la activi- 
dad de la angiogénesis del tumor, y promover la metástasis por el incremento de la adhesión celular. 2) Las citocinas como mediadores de la respuesta inmune pueden inhibir la expresión de las moléculas y receptores, tanto de las células de la respuesta inmune como de la célula tumoral, las cuales están involucradas en la identificación y destrucción de la célula tumoral (como la desregulación de las moléculas MHC clase I y II, de moléculas coestimuladoras y la desregulación de la cadena zeta del complejo $\mathrm{TcR} / \mathrm{CD} 3)^{14-17}$
En diferentes neoplasias, se ha observado una tendencia en la expresión de citocinas antiinflamatorias y una disminución de expresión de citocinas proinflamatorias. ${ }^{18-}$ ${ }^{20}$ Este cambio en la expresión de citocinas proinflamatorias a antiinflamatorias podría facilitar la progresión tumoral por la subversión de los mecanismos de inmunovigilancia celular. Particularmente, se ha observado un perfil de expresión de citocinas antiinflamatorias en pacientes con carcinoma cervical. ${ }^{21}$ En este sentido, la expresión de las citocinas IL-4, IL-10 y TGF- $\beta 1$ correlaciona con

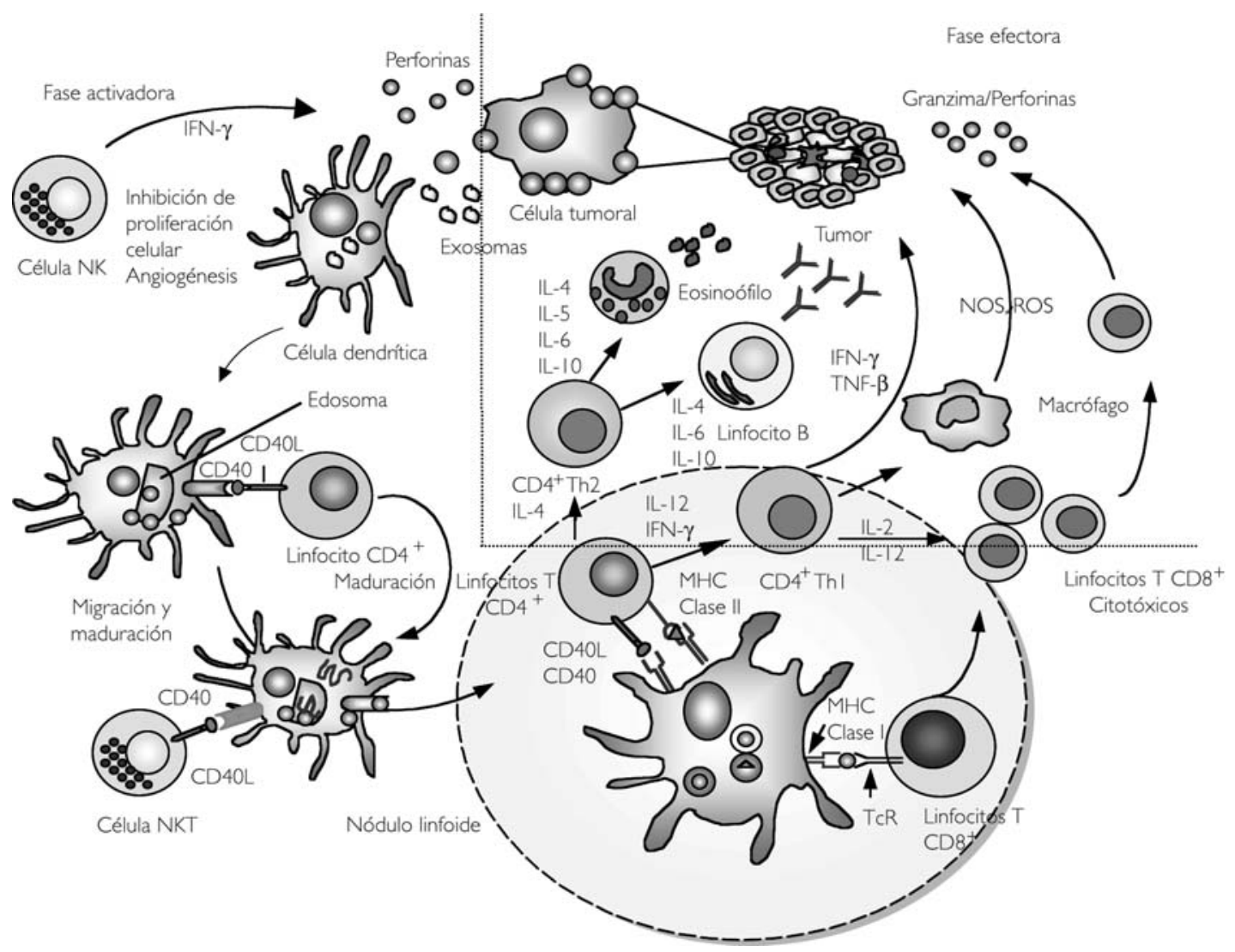

Figura I. Mediadores de la respuesta inmune contra tumores. La fase activadora de la respuesta inmune CONTRA TUMORES INICIA CON LA CAPTURA Y PROCESAMIENTO DE VESÍCULAS DE MEMBRANA LIBERADAS POR LAS CÉLULAS TUMORALES (EXOSOMAS) CAPTADAS POR LAS CÉLULAS DENDRÍTICAS (CD), LAS CUALES MIGRAN A LOS NÓDULOS LINFOIDES REGIONALES PARA ACTIVAR A LAS CÉlULAS DE LA RESPUESTA INMUNE (CROSS-PRIMING). Este PROCESO DE MADURACIÓNMIGRACIÓN DE LAS CD A LOS NÓdULOS LINFOIDES LO FACILITA LA INTERACCIÓN DEL RECEPTOR DEL CD40 DE LAS CD

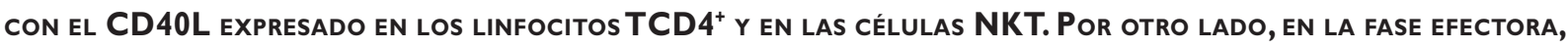
EL MATERIAL ENDOCITADO DEL TUMOR SE PRESENTA A LOS LINFOCITOST CD8 ${ }^{+}$Y CD4 ${ }^{+}$A TRAVÉS DE LAS MOLÉCULAS DEL MHC CLASE I Y II, RESPECTIVAMENTE. LOS LINFOCITOS T CD4 ${ }^{+}$ACTIVADOS SON DIFERENCIADOS EN LINFOCITOS T CD4 ${ }^{+}$ THI Y TH2 SEGÚN LAS CITOCINAS QUE SECRETAN, Y LAS CITOCINAS PUEDEN ACTIVAR A LA RESPUESTA INMUNE HUMORAL Y CELULAR. EN LA RESPUESTA INMUNE HUMORAL, LOS LINFOCITOS B ACTIVADOS PRODUCEN ANTICUERPOS ESPECÍFICOS CONTRA ANTÍGENOS TUMORALES, MIENTRAS QUE EN LA RESPUESTA INMUNE CELULAR, LOS LINFOCITOS T CD8 ${ }^{+}$CITOTÓXICOS ACTIVAdOS MIGRAN AL SITIO DEL TUMOR PARA RECONOCER Y MATAR A LA CÉLULA TUMORAL. 
la severidad de la enfermedad asociada con la infección del virus del papiloma humano. ${ }^{22-24}$ Por lo tanto, la expresión de un perfil de citocinas antiinflamatorias en el microambiente tumoral cervical favorece un estado de inmunosupresión local, el cual se asocia con la desregulación de varias moléculas de la respuesta inmune. ${ }^{25} \mathrm{En}$ favor de esta hipótesis, se ha informado sobre varias alteraciones de la respuesta inmune en pacientes con lesiones cervicales premalignas y malignas. Por ejemplo, se ha informado de una baja expresión de moléculas del MHC clase I asociada a la baja expresión de $\mathrm{TAP} 1,{ }^{26}$ de disminución de la expresión de moléculas coestimuladoras como B7 sobre la célula tumoral, ${ }^{27}$ de baja expresión de $\mathrm{CD} 25^{28} \mathrm{y}$ de la cadena $\zeta$ del complejo TcR/CD3 en linfocitos T infiltrantes de tumor y en células NKTs. ${ }^{29,30}$

\section{Citocinas como terapia génica contra el cáncer}

Las células tumorales tienen baja capacidad para activar a la respuesta inmune, como resultado de la disminución de la expresión de moléculas del MHC clase I y II, de moléculas de adhesión celular y de moléculas coestimuladoras. Esto impide la adecuada presentación de antígenos tumorales y la activación de los linfocitos T. Este efecto se confirma por la secreción de citocinas inmunosupresoras como IL-10 y TGF- $\beta 1$ y una nula expresión de citocinas proinflamatorias involucradas en la activación de la respuesta inmune.

Estos mecanismos de evasión a la respuesta inmune podrían superarse con la introducción de genes que codifiquen para moléculas inmunomoduladoras, dentro del microambiente tumoral. La identificación de las citocinas y quimiocinas como inductores de la maduración, activación y migración de células efectoras de la respuesta inmune ha permitido su uso como activadores de la respuesta inmune contra varios tumores. En varios modelos tumorales se ha determinado que las citocinas pueden favorecer la regresión del tumor, al activar la respuesta inmune mediada por células. Las citocinas IFN$\gamma$, IL-2, IL-12, IL-18 y el factor estimulador de colonias de granulocitos-monocitos (GM-CSF) recombinantes se han utilizado preferentemente como inmunoterapia contra el cáncer. Estas citocinas promueven la activación de linfocitos $\mathrm{T}$ contra antígenos tumorales, activan la respuesta inmune no especifica e inducen la expresión de otras citocinas activadoras. Además, pueden activar varias células de la respuesta inmune como: las células NK, monocitos y macrófagos. Estas citocinas favorecen la presentación de los antígenos específicos del tumor por parte de las propias células malignas. ${ }^{31}$ Sin embargo, la inmunoterapia con citocinas como activadores de la respuesta inmune está asociada con la vida media de estas citocinas y con la actividad tóxica a nivel sistémico. Por lo tanto, la terapia génica es la vía más factible para la administración local de estas citocinas. La liberación de los genes directamente en los tumores genera la expresión de los genes de las citocinas en las células del tumor, por lo que las altas dosis de las citocinas se producen en el ámbito local, y se reduce la toxicidad de la liberación de las citocinas recombinantes en el ámbito sistémico. ${ }^{32}$

\section{Citocinas como terapia génica en cáncer cervical}

El gran avance de las investigaciones en la terapia génica contra el cáncer cervical está enfocado principalmente a los oncogenes E6 y E7 del virus del papiloma humano (VPH), como antígenos específicos del tumor para generar inmunogenicidad tumoral. Estos genes se han usado en vacunas profilácticas y terapéuticas en diversas estrategias de terapia génica. En este sentido, se han inyectado simplemente los genes en el sitio del tumor como DNA desnudo, ${ }^{33-35}$ mediante el uso de una pistola de DNA (gene gun) ${ }^{36}$ o usando vehículos virales para liberar el material genético como: los vectores adenovirales, ${ }^{37}$ virus adenoasociados ${ }^{38} \mathrm{el}$ virus de vaccinia, ${ }^{39}$ alphavirus, ${ }^{40}$ el virus de estomatitis vesicular ${ }^{41}$ o speudovirus de VPH. ${ }^{42,43}$ Además, se han utilizado otros vehículos bacterianos como: Listeria monocytogenes, ${ }^{44}$ Salmonella typhimurium ${ }^{45}$ y Mycobacterium bovis. ${ }^{46}$ (cuadros I y II). Adicionalmente, otras proteínas de VPH como E1, E2, E4, E5, L1 y L2 se han considerado como antígenos de tumor para el control del cáncer cervical. $33,36,47$

Recientemente se demostró que las proteínas virales E5, E6 y E7 del VPH regulan la expresión de genes heterólogos celulares y pueden contribuir al desarrollo del cáncer cervical. ${ }^{48-50}$ Entre estos genes se encuentran la regulación de las citocinas IL-10 y TGF- $\beta 1$, lo cual correlaciona con la detección de estas citocinas en pacientes con cáncer cervical y con el desarrollo de un estado de inmunosupresión en el microambiente tumoral. Este mecanismo de evasión de la respuesta inmune es consistente con la desregulación de la inmunovigilancia tumoral de la que se informa en otros tipos de cáncer. A favor de revertir el efecto de inmunosupresión en el microambiente tumoral, se han empleado diferentes estrategias como la inhibición de las proteínas oncogénicas de VPH, la activación de la respuesta inmune específica del huésped en contra del VPH por el uso de antígenos específicos de $\mathrm{VPH}$, la inducción de la expresión de moléculas coestimuladoras (B7, cadena $\zeta$ de CD3, MHC clase I) y, muy importante, la administración de citocinas tipo Th1 para activar la respuesta inmune tipo celular. ${ }^{51}$ 
Los interferones (IFN), así como las citocinas IL-2, IL-12, y GM-CSF, se consideran como los principales inmunomoduladores de la respuesta inmune celular, y se han empleado en diversos modelos preclínicos contra el cáncer cervical..$^{52}$ De igual manera, diversas vías y vehículos de inmunización se han utilizado en diversos modelos tumorales murinos asociados al VPH (cuadro III).

Interferones: Los interferones son las citocinas más estudiadas como tratamiento para el cáncer cervical. Esta familia de citocinas tiene propiedades antivirales, antiproliferativas e inmunomoduladoras. ${ }^{53}$ Las lesiones cervicales asociadas al VPH y que se tratan con interferón recombinante pueden eliminar el virus $y$, en algunos casos, la infección latente. Sin embargo, el tratamiento con los IFN- $\alpha$ y $\gamma$ recombinantes en pacientes con neoplasias intraepiteliales cervicales (NICs) y en carcinomas cervicales bien establecidos, han generado resultados muy inconsistentes y su eficacia ha sido controversial. ${ }^{54-56}$ Es probable que estos resultados sean dependientes de los subtipos del interferón utilizados. El IFN- $\beta$ es más efectivo que el IFN- $\alpha$ y generalmente el IFN- $\gamma$ es el que tiene mayor efectividad contra neoplasias. Asimismo, la actividad tóxica del IFN- $\beta$ es muy alta comparada con drogas quimoterapéuticas, como el cisplatino, taxol y gemcitabine. ${ }^{57}$ Así, reiteradamente, la

\section{Cuadro II \\ VACUNAS QUE SE EMPLEAN EN TERAPIA GÉNICA}

Terapia génica

DNA desnudo

I. Generado (OJO) para expresar un antígeno tumoral específico

2. Fácil de producir y estable

3. Fácil de administrar: inyección directa o biobalística (gene gun)

4. Se puede aplicar en conjunto con adyuvantes

I. Es necesario conocer la secuencia del antígeno tumoral

2. Baja imunonigenicidad

3. Se requieren altas dosis del plásmido para generar una buena respuesta inmune

4. Baja capacidad de transfección

5. Inmunizaciones repetidas pueden inducir tolerancia

Vectores Virales

I. Generados para expresar un antígeno tumoral relevante

2. Pueden generarse para que coexpresen moléculas inmunoestimuladoras y citocinas

3. Amplia variedad de vectores virales

4. Alta capacidad de infección

5. Alta capacidad de transcripción del transgen

6. Se pueden generar para transcribir el gen terapéutico con promotores específicos
I. Inmunodominancia de antígenos virales sobre antígenos tumorales

2. Débil respuesta antitumoral observada en la mayoría de los vectores virales

3. Persistencia de la respuesta inmune contra los vectores virales que puede atenuar la respuesta antitumoral

4. Riesgo de toxicidad con los vectores vivos

5. Capacidad de integración del material genético viral al genoma de la célula huésped (retrovirus)
I. Se genera una respuesta inmune contra antígenos bacterianos sobre los antígenos tumorales

2 En dosis repetidas se generan anticuerpos en contra de antígenos bacterianos

3. Riesgo de infección de los vectores bacterianos
3. Son capaces de activar la respuesta inmune

vía oral y se puede generar una respuesta inmune sistémica

5. Se pueden dirigir antígenos tumorales a la superficie de la célula bacteriana

Vacunas basas en I. Pueden expresar un antígeno tumoral

células tumorales 2 . Los antígenos no necesariamente deben ser definidos

3. Pueden ser generadas para que coexpresen moléculas inmunoestimuladoras (citocinas)

4. Se genera respuesta inmune contra la célula tumoral
I. Se requiere capacitación de líneas celulares autólogas o alogénicas

2. Baja capacidad de presentación de antígenos

3. Amplio tiempo de producción

4. Gran costo, tiempo, manufactura
Células dendríticas I. Eficientes células presentadoras de antígenos modificadas
2. Disponibles para su uso en amplios protocolos clínicos

3. Pueden activarse con antígenos tumorales caracterizados o no caracterizados

4. Pueden activarse por múltiples antígenos y por diferentes técnicas (proteínas, péptidos, lisados celulares, vectores virales, etc.)
I. Se necesita cultivarlas ex vivo

2. Extensivo trabajo, costo y tiempo

3. Pueden generar tolerancia por las $C D$ inmaduras

4. Falta de criterios para estandarización del producto final 


\section{Cuadro III \\ USO DE TERAPIA GÉNICA EN MODELOS TUMORALES ASOCIADOS AL VIRUS DEL PAPILOMA HUMANO}

\begin{tabular}{|c|c|c|c|}
\hline Gen terapéutico & Terapia génica & Modelo tumoral & Referencia \\
\hline & & (Línea & \\
\hline Interferón- $\beta$ & Adenovirus & MEI80 & 59 \\
\hline IL-2, GM-CSF & Vacunas de tumor & TC-I, MKI6 & 73 \\
\hline IL-2 & Vacunas de tumor & MK-16 & 70 \\
\hline IL-2 & Vacunas de tumor & MK-16 & 69 \\
\hline IL-2, GM-CSF, & AAV & MK-16 & 72 \\
\hline Timidina cinasa & & & \\
\hline IL-2, DC & Vacunas de tumor & MK-16 & 68 \\
\hline IL-12, B7-I, B7-2 & Vacunas de tumor & BMK-I6/myc & 89 \\
\hline IL-I2 & DNA desnudo & TC-I & 86 \\
\hline IL-I2, E7 antisentido & DNA desnudo & $\mathrm{C} 3$ & 87 \\
\hline IL-12, E7 proteína & Adenovirus & ND & 88 \\
\hline IL-I2, E6 mutada & Gene gun & - & 91 \\
\hline GM-CSF, E8 de CRPV & Vacunas de tumor & BL-I & 81 \\
\hline & & (E7+ HPV I6) & \\
\hline$\overline{\text { GM-CSF, E7 CRPV }}$ & DNA desnudo & PC & 82 \\
\hline
\end{tabular}

L-12: Interleucina 12, GM-CSF: Factor estimulador de colonias de granulositos-monocitos, B7-I,B7-2: Moléculas coestimuladoras, CRPV: Papilomavirus de conejo cola de algodón, $\mathrm{CD}$ : Célula dendrítica,VAA:Virus Adenoasociados, TC-I, MK-I6, BMK-I6/myc, C3, BL-I: Líneas celulares transformadas con proteínas oncogénicas, o genoma completo del virus del papiloma, ND: No determinado, PC: Papilomas de conejo,

terapia génica local con IFN- $\beta$ tiene una amplia aplicación en la clínica en pacientes con cáncer. ${ }^{58}$ No obstante, respecto a la terapia génica con interferón para el tratamiento del cáncer cervical, hasta este momento sólo se ha demostrado el uso del IFN- $\beta$ en terapia génica en ratones desnudos, en un modelo tumoral generado con el uso de una línea celular de carcinoma cervical (ME180). En este modelo se demuestra que el uso de adenovirus recombinantes que expresan el gen de IFN$\beta$ es capaz de disminuir el desarrollo tumoral y la sobrevida de los ratones con tumor. ${ }^{59}$

Interleucina 2: La IL-2 es un potente activador de los linfocitos T, activa a las células NK, a los macrófagos, a los linfocitos B y estimula la liberación de varias citocinas. Su efecto antitumoral es mediado por promover la activación de las células NK, células asesinas activadas por linfocinas (LAK) y otras células citotóxicas, así como la inducción de IFN- $\gamma$, TNF- $\alpha .{ }^{60} \mathrm{El}$ uso de la IL-2 en terapia génica contra cáncer se ha empleado ampliamente en diversos modelos tumorales preclínicos, incluyendo el carcinoma hepatocelular, ${ }^{61}$ carcinoma de cabeza y cuello, ${ }^{62}$ sarcomas, ${ }^{63}$ plasmocitoma,${ }^{64}$ carcinoma de mama, ${ }^{65}$ linfomas, ${ }^{66}$ y en cáncer cervical ${ }^{67}$ Particularmente, el efecto adyuvante de la IL-2 en cáncer cervical se ha probado en modelos tumorales asociados al VPH. Se ha demostrado que el tratamiento con la proteína recombinante y con el gen de IL-2, administrados por vía intratumoral, reduce significativamente el avance de los tumores asociados al VPH e inhibe la formación de tumores recurrentes después de ser eliminados por cirugía. ${ }^{67,68}$ Por otro lado, en diversos modelos tumorales asociados al VPH, el desarrollo tumoral genera metástasis a pulmón y a nódulos linfoides. Sin embargo, el tratamiento basado en terapia génica con IL-2, administrada vía peritumoral, reduce el tamaño del volumen del tumor y el número de metástasis; y este efecto es dependiente de la expresión de moléculas MHC clase I por la propia célula tumoral. ${ }^{69}$ Además, se ha sugerido el tratamiento adicional con IFN- $\gamma$, para favorecer la expresión de las moléculas de MHC clase I y potenciar el efecto protector. ${ }^{70}$ Este mismo efecto protector se ha observado con la combinación de IL-12, ${ }^{71}$ y con el GMCSF. ${ }^{72,73}$ El mecanismo de inhibición del desarrollo tumoral por IL-2 se ha determinado por la capacidad para promover el infiltrado de los linfocitos $\mathrm{T}$ y células NKs al sitio del tumor, ${ }^{74}$ lo que aumenta el nivel de actividad lítica. ${ }^{75}$ Además, la presencia de IL-2 favorece la expresión de las subunidades $\beta$ y $\gamma$ del receptor de IL-2 en células tumorales asociadas a VPH, las cuales se requieren para los eventos de traducción de señales. ${ }^{76}$

GM-CSF: El factor estimulador de colonias de granulocitos-monocitos es un potente activador de la respuesta inmune antitumoral y se ha probado mediante terapia génica en diferentes modelos tumorales en animales y en ensayos clínicos en humanos. ${ }^{77-78}$

El uso del GM-CSF como adyuvante en la terapia génica contra cáncer cervical ha sido probado mediante el diseño ex vivo de líneas celulares tumorales, transformadas con las proteínas de VPH y transfectadas con el gen de GM-CSF. ${ }^{79}$ El tratamiento en modelos tumorales en ratón asociados al VPH y con la terapia génica $e x$ vivo ha permitido determinar que el GM-CSF es capaz de inhibir el desarrollo tumoral de una manera dosis dependiente ${ }^{80}$ Además, el tratamiento en conjunto de GM-CSF y la IL-2 aumenta la protección contra tumores recurrentes después de ser eliminados por cirugía e inhibe la formación de metástasis, las cuales no son inhibidas tan sólo con el tratamiento con el GM-CSF. ${ }^{73} \mathrm{Se}$ ha determinado que el efecto antitumoral del GM-CSF es dependiente del reclutamiento de APCs al sitio de inmunización, como las $\mathrm{CD}$, las cuales son consideradas como las más eficientes células inmuno-estimuladoras que presentan antígeno, y son capaces de activar a los linfocitos $\mathrm{T} \mathrm{CD} 4^{+}$y CD $8^{+}$antígeno-específicos. ${ }^{78}$ En este sentido, el efecto antitumoral del GM-CSF en la terapia génica contra el cáncer cervical es dependiente 
del resto de los antígenos virales del VPH, principalmente por las oncoproteínas E6 y E7. Por lo tanto, el tratamiento con el GM-CSF y la inmunización con los oncogenes E6 y E7 potencializa la respuesta de los linfocitos $\mathrm{T} \mathrm{CD} 8^{+}$citotóxicos antígeno-específicos contra E6/E7 y la protección antitumoral en tumores que expresan los mismos antígenos. ${ }^{81,82}$

Interleucina 12: La IL-12 es una citocina que por sus propiedades como inmunomodulador de la respuesta celular y de la actividad antitumoral se ha usado ampliamente en la terapia génica en diversos tumores murinos. Se han demostrado sus efectos en la inhibición del avance del tumor y reducción del número de metástasis experimentales. ${ }^{83-85}$ Es probable que la IL-12 sea una de las citocinas que más se usa como terapia génica contra el cáncer cervical. Su efecto adyuvante se ha demostrado en diversos modelos animales con tumor asociados al VPH. El tratamiento con el gen de IL12 se ha empleado usando la terapia génica no viral (DNA desnudo) ${ }^{86,87}$ terapia génica viral con el uso de adenovirus, ${ }^{88}$ terapia génica ex vivo, ${ }^{89} \mathrm{y}$ en combinación con los oncogenes E6 y E7, 77,88 así como con genes de moléculas inmunomoduladoras de la respuesta inmune celular como B7. ${ }^{89} \mathrm{El}$ efecto de represión del crecimiento tumoral se observa en todos los casos. Además, la IL-12 es capaz de inhibir la formación de metástasis experimentales y se considera como un buen candidato para el tratamiento basado en la terapia génica contra el cáncer cervical. El efecto antitumoral de IL-12 es dependiente de la activación y proliferación de los linfocitos $\mathrm{T}$ $\mathrm{CD} 8^{+}$citotóxicos, ${ }^{88} \mathrm{y}$ del aumento en la producción de IFN- $\gamma$ en el sitio de inmunización, el cual es producto de la activación de las células NK. ${ }^{84,88}$ Adicionalmente, el uso de IL-12 en la terapia génica contra el cáncer cervical se ha empleado en conjunto con otras citocinas como el GM-CSF e IL-2, donde ocurre un aumento del efecto protector contra el avance del tumor. ${ }^{90} \mathrm{Sin}$ embargo, el mejor efecto adyuvante se ha observado por la administración peritumoral de IL-12 y el GM-CSF.

De igual manera, se han probado diferentes combinaciones de citocinas como terapia génica en modelos tumorales experimentales asociados al VPH. La administración de IL-2 y el GM-CSF en conjunto inhiben el desarrollo tumoral y la formación de tumores residuales después de la cirugía o quimioterapia en sistemas experimentales. No obstante, el tratamiento únicamente con GM-CSF no tiene capacidad de inhibir la metástasis a pulmón, y se requiere de IL-12 para inhibir este proceso. ${ }^{73} \mathrm{Se}$ ha demostrado que el tratamiento simultáneo con IL-2, IFN- $\gamma$ y GM-CSF en un modelo tumoral experimental asociado al VPH-16, inhibe la formación de tumores recurrentes y no se detectan dife- rencias en la actividad citotóxica de los linfocitos $\mathrm{T}$ $\mathrm{CD} 8^{+}$del bazo. ${ }^{67}$ Por otro lado, la terapia génica con citocinas como tratamiento para el cáncer cervical ha sido probada en conjunto con terapias combinadas, usando RNA antisentido para E7,90 antígenos de $\mathrm{VPH},{ }^{82,88,91}$ terapia génica suicida, ${ }^{72,92}$ citocinas recombinantes ${ }^{73}$ y moléculas coestimuladoras de la respuesta inmune celular como B7-1 y B7-2. ${ }^{89,92}$

\section{Conclusiones}

En la actualidad el tratamiento contra diferentes enfermedades oncológicas ha evolucionado a pasos muy acelerados. Esto ha sido posible gracias a la influencia de la ingeniería genética y de la genómica en la medicina, que han permitido cambiar la perspectiva de los tratamientos y terapias contra las neoplasias. En este sentido, la terapia génica es una herramienta muy útil en la biomedicina moderna y, gracias a la capacidad de transferencia de DNA para corregir la acción de un gen alterado y favorecer la activación de la respuesta inmune, tiene un potencial enorme para el tratamiento, prevención o eliminación de algunos tipos de cáncer.

Recientemente, las investigaciones en torno al tratamiento de las neoplasias están enfocadas principalmente en conocer el origen del cáncer, las alteraciones celulares generadas durante la evolución tumoral y los mecanismos moleculares de la evasión de la respuesta inmune. Este conocimiento en conjunto con la biomedicina han permitido plantear el uso de nuevos fármacos, proteínas o el uso del DNA para controlar y/o corregir los defectos celulares, así como activar la respuesta inmune para eliminar a la célula tumoral.

De esta manera, las citocinas son excelentes candidatos para inhibir el avance del cáncer, ya que son consideradas como moléculas inmunoreguladoras que promueven la maduración, activación y migración de las células efectoras de la respuesta inmune al sitio de la neoplasia.

En particular, en el cáncer cervical, la terapia génica con citocinas promete ser una buena alternativa para corregir y controlar varias alteraciones de la respuesta inmune que se desarrollan en el microambiente tumoral de las pacientes con cáncer. La presencia de las citocinas IL-10 y TGF- $\beta 1$ ejerce un efecto de evasión e inhibición de la respuesta inmune, lo que puede controlarse con el uso de terapia génica con citocinas. El IFN- $\gamma$, IL-2, IL-12 y GM-CSF son excelentes candidatos como activadores de la respuesta inmune antitumoral y se han empleado en diversos modelos preclínicos con alta efectividad, pues con ellos se ha reducido la masa tumoral, el número de metástasis experimentales y en algunos casos eliminado el tumor completo. Adicionalmente, es posible utilizar la terapia génica con citocinas en combinación con quimio- 
cinas, con antígenos específicos de tumor, con moléculas coactivadoras, con adyuvantes y con el uso de diversos vehículos como acarreadores de los genes terapéuticos. En conclusión, este escenario permite proponer a la terapia génica con citocinas como una excelente estrategia para el tratamiento del cáncer cervical.

\section{Agradecimientos}

Victor Hugo Bermúdez Morales y Oscar Peralta Zaragoza son becarios del CONACyT con los números de expedientes 125098 y 117983, respectivamente.

\section{Referencias}

I. Smith KR. Gene therapy: theoretical and bioethical concepts. Arch Med Res 2003:34:247-268.

2. Bishop JM. Cancer the rise of the genetic paradigm. Genes Dev 1995;9:1309-1315.

3. Harris CC, Hollstein M. Clinical implications of the $p 53$ tumorsuppresor gene. New Engl J Med 1993;329:1318-I327.

4. Zhang Y, Mukhopadhyay T, Donehower LA, Georges RN, Roth JA.

Retroviral vector-mediated transduction of k-ras antisense RNA into human lung cancer cells inhibits expression of the malignant phenotype. Hum Gene Ther 1993;4:445-460.

5. Dachs GU, Dougherty GJ, Stratford IJ, Chaplin DJ. Targeting gene therapy to cancer: a review. Oncol Research 1997;9:3 13-325.

6. Pardoll D. Does the immune system see tumors as foreign or self?. Annu Rev Immunol 2003;21:807-839.

7. Sadelain M, Rivière I, Brentjens R. Targeting tumours with genetically enhanced T lymphocytes. Natl Rev Cancer 2003;3:35-45.

8. Pardoll DM, Topalian SL. The role of CD4+ T-cell responses in antitumor immunity. Curr Opin Immunol 1998; 10:588-594.

9. Toes RE, Ossendorp F, Offringa R, Melief CJM. CD4 T cells and their antitumor immune responses. J Exp Med 1999;189:753-756.

10. Paul WE. Pleiotropy and redundancy:T cell-dereived lymphokines in the immune response. Cell 1989;57:52I-524.

II. Schiepers OJ,Wicher MC, Maes M. Cytokines and major depression. Prog Neuropsychopharmacol Biol Psychiatry 2005;29:20I-2I7.

12. Dinarello CA. Proinflammatory cytokines. Chest 2000; I 8:503-508.

13. Giannini SL,Al-Saleh W, Piron H, Jacobs N, Doyen J, Boniver J, et al.

Cytokine expression in squamous intraepithelial lessions of the uterine

cervix: implications for generation of local immunosuppression. Clin Exp Immunol 1998; I13:183-189.

14. Nash MA, Ferrandina G, Loercher A, Freedman RS. The role of cytokines in both the normal and malignant ovary. Endocrine-Related Cancer 1999;6:93-107.

15. Matsuda M, Salazar F, Petersson M, Masucci G, Hanssonj, Pisa P, et al. Interleukin 10 pretreated protects target cells from tumor and allospecific cytotoxic T cells and downregulates HLA class I expression. J Exp Med 1994; 180:237I-2376.

16. Reichert TE, Rabinowich H, Johnson JT, Whiteside TL. Immune cells in the tumor microenviroment: mechanisms responsible for significant and functional defects. J Immunother 1998;21:295-306.

17. Taylor DD, Gercel-Taylor C, Lyons KS, Stanson J, Whiteside TL. T-cell apoptosis and suppression of T-cell resceptor/CD3-z by Fas ligandcontaining membrane vesicles shed from ovarian tumors. Clin Cancer Res 2003;9:5। 13-51।9.
18. Pisa P, Halapi E, Pisa EK,Gerdin E, Hising C, Bucht A, et al. Selective expression of interleukin 10 , interferon gamma, and granulocytesmacrophages colony-stimulating factor in ovarian cancer. Proc Natl Acad Sci USA 1992;89:7708-77/2.

19. Huang M, Wang J, Lee P, Sharma S, Mao JT, Meissner H, et al. Human non-small cell lung cancer cells express a type 2 cytokine pattern. Cancer Res 1995;55:3847-3853.

20. Kruger-Krasagakes S, Krasagakis K, Garbe C, Schmitt E, Huls C, Blankenstein $\mathrm{T}$, et al. Expression of interleukin 10 in human melanoma. Br J Cancer 1994;70: I 182-I I85.

2I.Wu T-C, Kurman RJ.Analysis of cytokine profiles in patients with human papillomavirus-associated neoplasms. J Natl Cancer Inst 1997;89:185-187.

22. De Grujil TD, Bontkes HJ, van de Muysengerg AJC, van Ostveen JW, Stukart MJ,Verheijen RHM, et al. Differences in cytokine mRNA profiles between premalignant and malignant lession of the uterine cervix. Eur J Cancer 1999;35:490-497.

23. Bor-Ching S, Rong-Hwa L, Huang-Chun L, Hong-Nerng Ho, Su-Ming $\mathrm{H}$, Su-Cheng H. Predominant Th2/Tc2 polarity of tumor-infiltrating lymphocytes in human cervical cancer.J Immunol 200 I;167:2972-2978. 24. Clerici M, Merola M, Ferrario E, Trabattoni D,Villa ML, Stefanon B, et al. Cytokines production patterns in cervical intraepithelial neoplasia: association with human papillomavirus infection. J Natl Cancer Inst 1997;89:245-250.

25. Sheu BC, Lin RH, Lien HC, Ho HN, Hsu SM, Huang SC. Predominant Th2/Tc2 polarity of tumor-infiltrating lymphocytes in human cervical cancer. J Immunol 2001;167:2972-2978.

26. Ritz U, Momburg F, Pilch H, Huber C, Maeurer MJ, Seliger B. Deficient expression of components of the MHC class I antigen processing machinery in human cervical carcinoma. Int J Oncol 2001;19:121I-1220.

27. Ellis JR, Keating PJ, Baird J, Hounsell EF, Renouf DV, Rowe M, et al. The association of an HPVI6 oncogene with HLA-B7 has implication for vaccine design in cervical cancer. Nat Med 1995; 1:464-470. 28. Sheu BC, Lin RH, Ho HN y Huang SC. Down-regulation of CD25 expression on the surface of activated tumor-infiltrating lymphocytes in human cervical carcinoma. Hum Immunol 1997;56:39-48.

29. De GruijITD, Bontkes HJ, Preccatori F, Galle MP, Helmerhorst TJ, Verheijen RH, et al. Expression of CD3-zeta on T-cells in primary cervical carcinoma and in metastasis-positive and -negative pelvic lymph nodes. Br J Cancer 1999;79: I I27-I I 32.

30. Kono K, Ressing ME, Brandt RM, Melief C], Potkul RK, Andersson B, et al. Decreased expression of signal-transducing zeta chain in peripheral $\mathrm{T}$ cells and natural killer cells in patients with cervical cancer. Clin Cancer Res 1996;2:1825-1828.

31. Dranoff G. Cytokines in cancer paphogenesis and cancer therapy. Nature Rev 2004:4:II-22.

32. Liu M,Acree B, Balloul JM, Bizouarne N, Paul S, Slos P, et al. Genebase vaccines and immunotherapeutics. Proc Natl Acad Sci USA 2004; I0I:|4567-| 457I.

33. Han R, Reed CA, Cladel NM, Christensen ND. Intramuscular injection of plasmid DNA encoding cottontail rabbit papillomavirus $\mathrm{EI}$, E2, E6 and E7 induces T cell-mediated but no humoral immune responses in rabbits. Vaccine 1999;17:1558-1566.

34. Shi W, Bu P, Liu J, Polack A, Fisher S, Qiao L. Human papillomavirus type $E 7$ DNA vaccine: mutation in the open reading frame of $E 7$ enhances specific cytotoxic T-lymphocyte induction and antitumor activity. JVirol 1999;73:7877-788I.

35. De Marco F, Hallez S, Brulet JM, Gesche F, Marzano P, Flamini S, et al. DNA vaccines against HPV-16 E7-expressing tumour cells. Anticancer Res 2003;23: 1449-1454.

36. Han R, Cladel NM, Reed CA, Peng X, Christensen ND. Protection of rabbits from viral challenge by gene gun-based intracutaneous 
vaccination with a combination of cottontail rabbit papillomavirus EI, E2, E6 and E7 genes. JVirol 1999:7039-7043.

37. He Z,Wlazlo AP, Kowalczyk DW, Cheng J, Xiang ZQ, Giles-davis W, et al.Viral recombinant vaccines to the E6 and E7 antigens of HPV-I6. Virol 2000;270:146-161.

38. Chiriva-Internati M, Lui Y, Salati E, Zhou W,Wang Z, Grizzi F, et al. Efficient generation of cytotoxic $T$ lymphocytes against cervical cancer cells by adeno-associated virus/human papillomavirus type 16 E7 antigen gene transduction into dendritic cells. Eur J Immunol $2002 ; 32: 30-38$. 39. Boursnell ME, Rutherford E, Hickling JK, Rollinson EA, Munro AJ, Rolley N, et al. Construction and characterization of a recombinant vaccinia virus expressing human papillomavirus proteins for immunoterapy of cervical cancer.Vaccine 1996; | 4: I 485- I 494. 40.Velders MP, McElhiney S, Cassetti MC, Eiben GL, Higgins T, Kovacs $\mathrm{GR}$, et al. Eradication of established tumors by vaccination with Venezuelan equine encephalitis virus replicon particles delivering human papillomavirus 16 E7 RNA. Cancer Res 2001;61:786I-7867. 4I. Reuter JD,Vivas-Gonzalez BE, Gomez D,Wilson JH, Brandsma JL, Greenstone $\mathrm{HL}$, et al. Intranasal vaccination with a recombinant vesicular stomatitis virus expressing cottontail rabbits papillomavirus LI protein provides complete protection against papillomavirus-induced disease. JVirol 2002;76:8900-8909.

42. Shi W, Liu J, Huang Y, Qiao L. Papillomavirus pseudovirus: a novel vaccine to induce mucosal and systemic cytotoxic T-lymphocytes responses. JVirol 2001;75:10139-10148.

43. Gunn GR, Zubair A, Peters C, Pan ZK, Wu TC, Paterson Y.Two Listeria monocytogenes vaccine vectors that express different molecular forms of human papillomavirus- I6 (HPV-I6) E7 induce qualitatively different $T$ cell immunity that correlates with their ability to induce regression of established tumors immortalized by HPV-16. J Immunol 200I;167:647I-6479.

44. Lin CW, Lee JY,Tsao YP, Shen CP. Lai HC, Chen SL. Oral vaccination with recombinant Listeria monocytogenes expressing human papillomavirus type $16 \mathrm{E7}$ can cause tumor growth in mice to regress. Int J Cancer 2002;629-637.

45. Revaz V, Benyacooub J, Kast WM, Schiller JT, De Grandi P, NardelliHaefliger D. Mucosal vaccination with a recombinant Salmonella typhimurium expressing human papillomavirus type I6 (HPVI6) LI virus-like particles (VLPs) or HPVI6VLPs purified from insect cells inhibits the growth of HPVI6-expressing tumors cells in mice.Virology 200I;279:354-360.

46. Jabbar IA, Fernando GJ, Saunders N,Aldovini A, Young R, Malcolm K, Frazer IH. Immune responses induced by BCG recombinant for human papillomavirus LI and E7 proteins. Vaccine 2000; I8:2444-2453. 47. Liu DW, Tsao YP, Hsieh JT, Kung JT, Chiang CL, Huang SJ, et al. Induction of CD8 $\mathrm{T}$ cells by vaccination with recombinant adenovirus expressing human papillomavirus type 16 E5 gene reduces tumor growth. J Virol 2000;74:9083-9089.

48. Morosov A, Phelps CW, Raychaudhuri P.Activation of the c-fos gene by the HPVI6 oncoprotein depends upon the CAMP-response elements at -60. J Biol Chem 1994;269:18434- I8440.

49. Show-Li C,Ying-Kuang L, Long-Yuan L, Yeou-Ping T, Hsiang-Yun L, Won-Bo W, et al. E5 proteins of human papillomavirus types II and I6 transactivate the c-fos promoter througt the NFI binding element. J Virol 1996;70:8558-8563.

50. Dey A, Atcha IA, Bagchi S. HPV I6 E6 oncoprotein stimulates the transforming growth factor-bl promoter in fobroblast through a specific GC-rich sequence.Virology 1997;228:190-199.

5I. Kaufman AM, Gissman L, Simms P, Schreckenberger C, Qioa L. Comparation of cytokines and CD80 for enhancement of immunogenicity of cervical cancer cells. Immunobiol 2000;202:339-352. 52. Idrova M, Mikyskova R, Jandlova T,Vonka V, Bubenik J, Bieblova J. Adjuvant cytokine treatment of minimal residual disease after surgical therapy in mice carrying HPVI6-associated tumours: cytolytic activity of spleen cells from tumour regressors. Folia Biol 2003;49:2 17-222.

53. Vilcek J, Sen GC. Interferons and other cytokines: In: Fields BN, Knipe DM, Howley PM, ed. Fields Virology. Philadelphia: LippincottRaven.(OJO:AÑO)

54. Koromilas AE, Li S, Matlashewski G. Control of interferon signaling in human papillomavirus infection. Cytokine Growth Factor Rev 200I; I2:157- I70.

55. Wadler S, Burk RD, Neuberg D, Rameau R, Runowicz CD, Goldberg $G$, et al. Lack of efficacy of interferon-alpha therapy in recurrent advanced cervical cancer. J Interferon Cytokine Re 1995; 15:101 I-1016. 56. Sikorski M, Zrubek H. Long-term follow-up of patients treated with recombinant human interferon gamma for cervical intraepithelial neoplasia. Int J Gynaecol Obstet 2003;82: 179-85

57. Brickelmaier M, Carmillo A, Goelz S, Barsoum J, Qin XQ.

Cytotoxicity of combinations of IFN-beta and chemotherapeutic grugs. J Interferon Cytokine Res 2002;22:873-880.

58. Yoshida J, Mizuno M,Wakabayashi T. Inteferon-beta gene therapy for cancer: Basic research to clinical application. Cancer Sci 2004;95:858-865. 59. Qin X, Tao N, Dergay A, Moy P, Fawell S, Davis A, et al. Interferonbeta gene therapy inhibits tumor formation and causes regression of established tumors in immune-deficient mice. Proc Natl Acad Sci USA 1998;95: |44| I-|44|6.

60. Whittington R, Fauds D. Interleukin-2.A review of its pharmacological properties and therapeutic use in patients with cancer. Drugs 1993;46:446-5I4

6I.Yang JH, Fan RF, Qian QJ, You TG, Xue HB, Su CQ, et al. Treatment of hepatocellular carcinoma by transfecting interleukin- 12 and interleukin 2 fusion gene intraplenically, an experimental study. Zhonghua Yi Xue Za Zhi 2003;10:740-743.

62. Lui SX, Yang H, Yuan YM, Guo YF. Tang ZQ, Liang CY. Combination radiation and gene therapy for head and neck squamous cell carcinoma in the murine model. Zhonghua Er Bi Yan Hou Ke Za Zhi 2004;39:278-282. 63. VIk V, Rossner P, Indrova M, Bubenik J, Sobota V. Interleukin-2 gene therapy of surgical minimal residual tumour disease. Int J Cancer 1998;30: II5-II9.

64. Bubenik J, Simova J, Zeuthen J, Diamant M, Jandlova T, Bubenikova D. Gene therapy of plastocytoma: comparison of the therapeutic efficacy of tumour cells transduced with the interleukin-2, interleukin-4, or interleukin-6 genes. Folia Biol 1994;40:29-36.

65. Deshmukh P. Glick RP, Lichtor T, Moser R, Cohen EP. Immunogene therapy with interleukin-2-secreting fibroblasts for intracerebrally metastasizing breast cancer in mice. J Neurosurg 200 I;94:287-292 66. Jiang $\mathrm{Q}, \mathrm{Da}$ W, Ou Y. Experimental study of interleukin- 12 gene vaccines in the treatment of low-load malignant lymphoma (EL4). Zhonghua Xue Ye Xue Za Zhi 200I;22:565-568.

67. Indrova M, Mikyskova R, Jandlova T,Vonka V, Bubenik J, Bieblova J. Adjuvant cytokine treatment of minimal residual disease after surgical therapy in mice carrying HPVI6-associated tumours: cytolytic activity of spleen cells from tumour regressors. Folia Biol 2003;49:217-222. 68. Bubenik J, Mikyskova R,Vonka V, Mendoza LÑ, Simova J, Smahel M, et al. Interleukin-2 and dendritic cells as adjuvants for surgical therapy of tumours associated with human papillomavirus type 16.Vaccine 2003;21:891-896.

69. Bubenik J, Simova J, Hajkova R, Sobota V, Jandlova T, Smahel M, et al. Interleukin 2 gene therapy of residual disease in mice carrying tumours induced by HPV I6. Int J Oncol 1999; | 4:593-597.

70. Indrova M, Bubenik J, Mikyskova R, Vonka R, Smahel M, Zak R, et al. Tumour-inhibitory and antimetastatic effects of IL-2 in mice carrying MHC class I-tumours of HPVI6 origin. In J Oncol 2002;20:643-646. 7I. Mikyskova R, Bubenik J, Mendoza L,Vonka V, Smahel M, Simova J, et al. Local cytokine treatment of HPVI6-associated tumours results in inhibition of their lung metastases. Clin Exp Metastasis 2000; 18:58I-587. 
72. Jinoch P, Zak R, Janouskova O, Kunke D, Rittich S, Duskova M, et al. Immunization with live HPV-16-transformed mouse cells expressing the herpes simplex thymidine kinase and either GM-CSF or IL-2. Int J Oncol 2003;23:775-783.

73. Mikyskova R, Indrova M, Simova J, Jandlova T, Bieblova J, Jinoch P, et al. Treatment of minimal residual disease after surgery or chemotherapy in mice carrying HPVI6-associated tumours: Cytokine and gene therapy with IL-2 and GM-CSF. Int J Oncol 2004;24:16I-167.

74. Chen J, Cao XY, Zhang P, Peng ZL, Yang YL,Bi JH. Study on the TIL and NK of IL-2 injected via pelvic retroperitoneal space in gynecological cancer patient. SiChuan Da Xue Xue Bao Yi Xue Ban 2004;35:406-408. 75. Verma V, Sharma V, Shrivastava SK, Nadkarni JJ. IL-I2, IL-2 potentiate the in vitro tumor-specific activity of peripherial blood cells from cervical cancer patients.J Exp Clin Cancer Res 2000;19:367-374.

76. Casana PH, Hernandez H,Arana MJ. Interleukin-2 inhibits proliferation of HPV-associated tumor cells and halts tumor growth in vivo. Biochem Biophys Res Commun 2002;299:818-824.

77. Simons JW, Mikhak B, Chag JF, DeMarzo AM, Carducci MA, Lim M, et al. Induction of immunity to prostate cancer antigens: Results of a clinical trial of vaccination with irradiated autologous protate tumor cells engineered to secrete granulocyte-macrophage colony-stimulating factor using ex vivo gene transfer. Cancer Research 1999;59:5 160-5168. 78. Pan PY, LiY, Li Q, Gu P, Martinet O, Thung S, et al. In situ recruitment of antigen-presenting cells by intratumoral GM-CSF gene delivery. Cancer Immunol Immunother 2004;53:17-25.

79. Nelson WG, Simons JW, Mikhak B, Chang JF, DeMazo AM, Carducci $M A$, et al. Cancer cells engineered to secrete granulocyte-macrophage colony-stimulating factor using ex vivo gene transfer as vaccines for treatment of genitourinary malignancies. Cancer Chemother. Pharmacol 2000;46:S67-72.

80. Li J, Bouton-Verville H, Holmes LM, Burgin KE, Jakubchak S, Yu X, et al. Inhibition or promotion of tumor growth by granulocytesmacrophage colony-stimulating factor derived from engineered tumor cells is dose-dependent. Anticancer Res 2004;24:2717-2721.

8I. Chang EY, Chen CH, Ji H, Wang TL, Lee BP, Huang AY, et al. Antigenspecific cancer immunotherapy using a GM-CSF secreting allogeneic tumor cell based vaccine. Int J Cancer 2000;86:725-730.

82. Leachman SA, Tigelaar RE, Schlyankevich M, Slade MD, Irwin M, Chang E, et al. Granulocyte-macrophage colony-stimulating factor priming plus papillomavirus E6 DNA vaccination: effects on papilloma formation and regression in the cottontail rabbit papillomavirus-rabbit model. J Virol 2000;74:8700-8708.

83. Song K, Chang Y, Prud'homme GJ. IL-I2 plasmid-enhanced DNA vaccination against carcinoembryonic antigen (CEA) studied in immune gene knockout mice. Gene Therapy 2000;7: 1527-1535.

84. Thomas GR, Chien Z, Enamorado I, Bancroft CVan,Waes C. IL-I2 and IL-2- induced tumor regression in a new murine model of oral squamous-cell carcinoma is promoted by expression of the CD80 costimulatory molecule and interferon-g. Int J Cancer 2000;86:368-374. 85. Hull GW, Mccurdy MA, Nasu Y, Bangma, Yang G, Shimura S, et al. Prostate cancer gene therapy: comparison of adenovirus-mediated expression of inteleukin 12 with interleukin 12 plus B7-I for in situ gene therapy and gene-modified cell-based vaccines. Clin Cancer Res 2000;6:410I-4109.

86. LuiVW, He Y, Falo L, Huang L. Systemic administration of naked DNA encoding interleukin 12 for the treatment of human papillomavirus DNA-positive tumor. Hum GeneTher 2002;13:177-185. 87. He YK, LuiVW, Baar J,Wang L, Shurin M, Almonte C, et al. Potentiation of E7 antisense RNA-induced antitumor immunity by codelivery of IL-12 gene in HPVI6 DNA-positive mouse tumor. Gene Ther 1998:5: | 462-147I.

88. Ahn WS, Bae SM, Kim TY, Kim TG, Lee JM, Namkoong SE, et al. A therapy modality using recombinant IL- 12 adenovirus plus E7 protein in a human papillomavirus 16 E6/E7-associated cervical cancer animal model. Hum Gene Ther 2003; 14:1389-1399.

89. Hallez S, Detremmerie O, Giannouli C, Thielemans K, Gajewski TF, Burny A et al. Interleukin-12-secreting human papillomavirus type 16transformed cells provide potent cancer vaccine that generates E7directed immunity. Int J Cancer 1999;81:428-437.

90. Indrova M, Bubenik J, Mikyskova R, Mendoza L, Simova J, Bieblova J, et al. Chemoimmunotherapy in mice carrying HPVI6-associated, MHC class I+ and class I-tumours : Effects of CBM-4A potentiated with IL-2, IL-I2, GM-CSF and genetically modified tumour vaccines. Int J Oncol 2003;22:691-695.

91. Tan J, Yang NS, Turner JG, Niu GL, Maassab HF, Sun J, et al. Interleukin-12 cDNA skin transfection potentiates human papillomvirus E6 DNA vaccine-induced antitumor immune response. Cancer Gene Ther 1999;6:331-339.

92. Janouskova O, Sima P, Kunke D. Combined suicide gene and immunostimulatory gene therapy using AAV-mediated gene transfer to HPV-16 transformed mouse cell: decrease oncogenicity and induction of protection. Int J Oncol 2003;22:569-577. 